\title{
IMPLEMENTASI MANAJEMEN "RE" UNTUK MENGURANGI JAM KOSONG SERTA KETERLAMBATAN GURU DATANG DAN MASUK KELAS DI SD NEGERI 163099
}

\author{
Nurmala Tampubolon \\ Surel: nurmalatampubolon29@gmail.com
}

\begin{abstract}
The purpose of writing to reduce school hours, reduce the number of teachers who are late in school, reducing the number of teachers who are late to class. The cycle pattern that the authors offer starts from the control, improvement/improvement, maintenance, action, planning, inspection and implementation. Control needs to be done on input products, process work (KBM) or PBM implementation until the end of output. Therefore, it is necessary to develop a "quality mentality mentality" attached to the processor (built in quality) and implement (do it right the first time). From the results obtained it can be conveyed here that with the management of RE can reformat teacher discipline and effect on student discipline, which finally will realize the school effective and superior. Writing is expected not only a big dreaming, but also can be done and implemented from the small (start from little) which then through the action (do it now).
\end{abstract}

Keywords: Management Implimentation, RE, School Displin

\begin{abstract}
ABSTRAK
Tujuan dari penulisan untuk mengurangi jam kosong di sekolah, mengurangi jumlah guru yang terlambat datang di sekolah, mengurangi jumlah guru yang terlambat masuk kelas. Adapun polasiklus yang penulis tawarkan dimulai dari pengendalian, perbaikan/peningkatan, pemeliharaan, tindakan, perencanaan, pemeriksaan dan pelaksanaan. Dari hasil yang diperoleh dapat disampaikan disini bahwa dengan manajemen RE dapat menformat disiplin guru dan berefek pada disiplin siswa, yang akhirnya akan mewujudkan sekolah yang efektif dan unggul. Karya tulis ini diharapkan bukan hanya sebuah tulisan yang bermimpi besar (dream big) saja, tetapi juga dapat dilakukan dan di implementasikan mulai dari yang kecil (start from little) yang kemudian melalui tindakan (do it now).
\end{abstract}

Kata Kunci : Displin Sekolah, Implimentasi Manajemen, RE

\section{PENDAHULUAN}

Disadari atau tidak disadari, guru adalah panutan bagi siswa di sekolah dimana ia bertugas. Oleh karena itu apapun yang dilakukan oleh guru selalu menjadi contoh bagi anak didiknya. Jika gurunya masih ada yang datang terlambat di sekolah atau terlambat masuk kelas, jangan harap siswanya dapat hadir tepat waktu atau masuk kelas sesuai dengan jam bel masuk. Penulis prihatin jika menyaksikan ada guru

Guru SD Negeri 163099 
yang datang ke sekolah terlambat, atau masuk kelas tidak sesuai dengan bel masuk atau bahkan ada guru yang sering meninggalkan jam mengajar dengan alasan yang tidak jelas. Hal tersebut terjadi pada sekolah tempat penulis bertugas. Pada saat itu tingkat kosong jam tinggi, guru terlambat datang menjadi pemandangan seharihari dan guru terlambat masuk kelas menjadi kebiasan yang membudaya. Dalam keadaan tersebut penulis ingin mengubah kondisi itu menjadi kondisi yang disiplin. Oleh karena itu penulis mengimplementasikan manajemen RE untuk mengurangi jam kosong, keterlambatan guru datang di sekolah dan keterlambatan guru masuk kelas. Sehingga judul penelitian ini adalah: Implementasi Manajemen RE untuk mengurangi Jam Kosong, Keterlambatan Guru datang di sekolah, Keterlambatan Guru Masuk Kelas di SDN 163099 Tebing Tinggi.

Dari latar belakang tersebut diatas, maka dapat dirumuskan permasalahan sebagai berikut :

1. Sejauhmana Manajemen RE dapat mengurang jam kosong di SDN 163099 Tebing Tinggi ?

2. Sejauhmana Manajemen RE dapat mengurangi jumlah guru yang terlambat datang ke sekolah?

3. Sejauhmana manajemen RE dapat mengurangi Jumlah guru yang terlambat masuk kelas ?

Dari 3 permasalahan tersebut, penulis akan bahas dan uraikan dalam

rangka membantu pemikiran untuk memecahkan masalah-masalah yang sering terjadi di sekolah.

Tujuan penelitian ini adalah untuk meningkatkan kedisiplinan di SDN 163099 Tebing Tinggi melalui peningkatan disiplin guru. Sedangkan tujuan khusus dari penelitian ini adalah:

1. Untuk mengurangi jam kosong di sekolah.

2. Untuk mengurangi jumlah guru yang terlambat datang di sekolah.

3. Untuk mengurangi jumlah guru yang terlambat masuk kelas.

Manfaat penelitian ini adalah :

1. Bagi sekolah

Meningkatkan kedisiplinan warga sekolah secara keseluruhan antara lain Kepala Sekolah, Wakil Kepala Sekolah, Guru, Siswa, Tenaga Kependidikan lainnya / Staf Administrasi Sekolah, Staf Penunjang (Petugas kebersihan, Petugas Pertamanan, Satpam, dan Penjaga Sekolah) Orang Tuan siswa / Pengurus Komite Sekolah dan yang menjadi kunci dari kedisiplinan adalah kepala sekolah, guru dan siswa.

\section{Bagi Kepala Sekolah \\ Memudahkan dalam memantau disiplin warga sekolah, secara keseluruhan baik guru, siswa maupun staf tata usaha.}

3. Bagi Guru

Tanpa terasa guru dapat 
Nurmala Tampubolon: Implementasi Manajemen ..

berusaha menyesuaikan dengan kesepakatan yang sudah dibuat pada saat awal semester, yaitu menuju kedisiplinan yang tinggi.

\section{Bagi Siswa}

Mendapatkan pelajaran yang sangat berharga yaitu contoh disiplin yang diinginkan sekolah.

\section{Bagi Orang tua}

Dengan disiplin tinggi di sekolah orang tua tidak usah khawatir anaknya beraktifitas di luar kegiatan belajar mengajar di sekolah.

\section{METODE PENELITIAN}

Dalam mengimplementasikan manajemen RE ini penulis menggunakan tiga siklus sebagai berikut :

\section{Siklus Pertama}

Siklus pertama dilaksanakan pada semester 1 tahun pelajaran 2016/2017, dimana pada saat itu di awal semester diadakan rapat pembagian jam mengajar dengan kesepakatan bahwa kita harus meningkatkan disiplin siswa dan kita awali dari disiplin kepala sekolah, guru dan karyawan dengan langkah :

a. Merencanakan penempatan guru sebagai wakil kepala sekolah, wali kelas, guru mata pelajaran, Guru BK, guru ekstrakurikuler, guru piket.

b. Menfungsikan masing-masing guru tersebut secara maksimal.

c. Menyiapkan Buku point siswa

d. Menyiapkan absensi kehadiran guru

e. Menyiapkan Buku Ijin Guru

f. Menyiapkan buku piket guru.

g. Melaksanakan kegiatan sesuai dengan kesepakatan tersebut.

\section{Siklus Kedua}

Siklus kedua ini dilaksanakan pada semester 2 tahun pelajaran 2016/2017 dimana pada awal semester 2 diadakan rapat pembagian raport dengan agenda rapat sebagai berikut :

a. Evaluasi kehadiran guru dari buku kehadiran guru oleh kepala sekolah.

b. Evaluasi disiplin siswa dari buku point oleh wali kelas.

c. Merencanakan penanganan bagi siswa yang point nya melebihi 40 point dalam satu semester.

d. Merumuskan sanksi bagi guru yang meninggalkan jam mengajar lebih dari 5 kali dalam satu semester, mulai dipanggil, diperingatkan secara lisan, tertulis atau pengurangan jam mengajar.

e. Melaksanakan program sesuai dengan kesepakatan di awal semester.

Pada siklus kedua ini ada peningkatan tindakan yaitu pemberian sanksi bagi siswa dan guru yang melanggar disiplin sesuai dengan kesepakatan pada awal semester.

\section{Siklus Ketiga}

Siklus ketiga ini dilaksanakan pada semester 1 tahun pelajaran 
2016/2017 yang diawali pada rapat pembagian jam mengajar dengan agenda sebagai berikut :

a. Evaluasi Disiplin siswa oleh Wali kelas.

b. Evaluasi Disiplin guru oleh Wakasek Kurikulum.

c. Merencanakan rumusan tugas masing-masing guru secara jelas, termasuk yang berhak memperingatkan siswa yang melanggar tata tertib, tidak hanya wali kelas dan BK tetapi semua bapak/ibu guru berhak mengingatkan siswa. Demikian juga yang berhak mengingatkan guru yang melanggar kesepakatan adalah Wakasek dan guru Piket.

d. Melaksanakan program sesuai dengan tugas pokok dan fungsi yang sudah tertulis dan ditanda tangani oleh kepala sekolah.
Pada Siklus ketiga ini ada peningkatan tindakan yaitu memperluas pengambil langkah untuk mengingatkan bagi warga sekolah yang melanggar kesepakatan. Hal ini dapat berjalan karena tugas pokok dan fungsi sudah tertulis secara rinci, sehingga akan kelihatan siswa yang melanggar dan sanksinya juga jelas, demikian juga guru yang melanggar kesepakatan akan mudah diingatkan dengan mengembalikan pada tugas pokok dan fungsinya.

Pengumpulan data dibantu oleh tata usaha melalui rekap buku kehadiran guru, buku ijin guru. Data yang diperoleh direkap dan disajikan dalam bentuk tabel.

Data yang sudah terkumpul disusun dalam tabel dan dinyatakan dalam bentuk prosentase antara lain mengenai Jumlah Jam Kosong, Jumlah guru terlambat datang ke sekolah, dan jumlah guru yang terlambat masuk kelas.

\section{HASIL DAN PEMBAHASAN}

Dari hasil pengumpulan data diperoleh hasil sebagai berikut:

Tabel. Data Guru Diperoleh Dari Rekapitulasi Yang Dibuat Oleh Tata Usaha, Dan Data Siswa Diperoleh Dari Guru BK Dan Wali Kelas.

\begin{tabular}{|c|l|c|c|c|}
\hline No & \multicolumn{1}{|c|}{ Jenis Kegiatan } & Siklus 1 & Siklus 2 & Siklus 3 \\
\hline 1 & Rata-rata Jumlah Jam Kosong & $12 \%$ & $5 \%$ & $3 \%$ \\
\hline 2 & Rata-rata guru terlambat dating kesekolah & $25 \%$ & $20 \%$ & $5 \%$ \\
\hline 3 & Rata-rata guru terlambat masuk kelas & $30 \%$ & $25 \%$ & $10 \%$ \\
\hline 4 & Rata-rata siswa bolos sekolah & $15 \%$ & $4 \%$ & $2 \%$ \\
\hline 5 & Rata-rata siswa terlambat dating kesekolah & $16 \%$ & $8 \%$ & $3 \%$ \\
\hline 6 & Rata-rata siswa terlambat masuk kelas & $20 \%$ & $6 \%$ & $1 \%$ \\
\hline
\end{tabular}

Dari data yang terkumpul tampak bahwa dengan menggunakan 
manajemen RE ditambah dengan peningkatan langkah dan tindakan terjadi peningkatan yang berarti yaitu:

1. Rata-rata jam kosong

Rata-rata jam kosong menurun secara berarti dimana siklus satu $12 \%$ dan pada siklus dua sebesar 5\% dan pada siklus tiga menjadi 3\%. Pada siklus satu guru mudah sekali meninggalkan tugas mengajarnya, sehingga jika di sekolah total jam belajar ada $300 \mathrm{Jam} /$ minggu :

- $\quad$ Siklus satu $12 \%$ nya atau sebesar 36 jam kosong/minggu atau 144 Jam kosong/bulan atau kira-kira 720 jam kosong/semester.

Siklus kedua $5 \%$ nya atau sebesar 15 jam kosong/minggu atau 60 Jam kosong/bulan atau kira-kira $\quad 300 \quad$ jam kosong/semester.

- $\quad$ Siklus ketiga $3 \%$ nya adalah sebesar 9 jam kosong/minggu atau 36 jam kosong/bulan atau kira-kira 45 jam kosong/ semester.

Sampai pada siklus ketiga sudah kita anggap wajar dengan tingkat kosong jam $3 \%$ tersebut.

2. Rata-rata guru terlambat datang ke sekolah

Rata-rata guru terlambat datang ke sekolah menurun secara berarti yaitu pada siklus satu $25 \%$ dan pada siklus dua $20 \%$ dan $5 \%$ pada siklus tiga. Ini berarti jika di SDN 163099 Tebing Tinggi ada 24 guru, maka :

- Siklus satu 25\% nya atau sebesar
6 orang guru/minggu yang terlambat atau 24 orang guru/bulan atau kira-kira 120 orang guru/semester.

- Siklus satu 20\% nya atau sebesar 4 orang guru/minggu yang terlambat atau 16 orang guru/bulan atau kira-kira 80 orang guru/semester.

- Siklus satu 5\% nya atau sebesar 1 orang guru/minggu yang terlambat atau 4 orang guru/bulan atau kira-kira 20 orang guru/semester.

Pada akhir siklus ketiga dianggap wajar dan dapat dimaklumi dengan jumlah guru yang terlambat $5 \%$ itu pun sebagian besar tanpa ada kesengajaan.

3. Jumlah Guru yang terlambat masuk kelas

Rata-rata jumlah guru yang terlambat masuk kelas terjadi peningkatan yang berarti yaitu siklus pertama sebesar $30 \%$, dan $25 \%$ pada siklus dua serta $10 \%$ pada siklus tiga. Ini berarti jika di SDN 163099 Tebing Tinggi ada tiga kali pergantian guru dalam sehari kali 9 kelas, maka ada 27 kali pergantian jam.

- $\quad$ Siklus satu $30 \%$ x $27=9$ guru yang terlambat masuk kelas/hari, atau 54 guru/minggu atau 216 guru/bulan.

- Siklus satu $25 \%$ × $27=6$ guru yang terlambat masuk kelas/hari, atau 36 guru/minggu atau 144 guru/bulan.

- Siklus satu $10 \%$ x $27=3$ guru 
yang terlambat masuk kelas/hari, atau 18 guru/minggu atau 72 guru/bulan.

Pada siklus ketiga masih cukup tinggi, namun efek jera bagi siswa sudah cukup baik, karena siswa masih mengganggap guru adalah panutan.

\section{Disiplin Siswa}

Disiplin siswa meningkat seiring meningkatnya disiplin guru, ini berarti memang guru adalah kunci keberhasilan penegakan disiplin di sekolah.

Untuk

mendorong

ketercapaian tujuan sekolah sebagai lembaga pengembang dan pembangun sumberdaya manusia serta mengukur kemampuan sekolah untuk tetap exist dan maju, maka perlu adanya perumusan dan analisa sekolah, analisa pasar dan analisa hasil dengan model EKSF atas dasar manajemen RE tersebut untuk mendapatkan seluruh qualifiededucational share. Tetapi untuk mendapatkan seluruh qualifiededucational share tersebut, diperlukan resources yang sangat besar sehingga akan menimbulkan masalah dalam keberhasilan dan keuntungan lembaga dikemudian hari. Maka sekolah perlu membatasi diri dengan menetapkan School Key Success Factor (SKSF) yang reasonable.EKSF bersifat dinamis, bergerak sesuai dengan tuntutan stakeholder yang makin meningkat, kecepatan tersebut tergantung pada situasi saat itu. Beberapa hal yang perlu diperhatikan menentukan EKSF adalah sebagai berikut :

1. Apa dan bagaimana kondisi pendidikan yang sedang dijalani saat ini? (identifikasi apakah implisit dan eksplisit strategi saat ini, Analisa SWOT dan kondisi persaingan).

2. Apa yang terjadi dengan lingkungan pendidikan? (Educational analysis, Competitor analysis, Social analysis, Strength \& Weakness yang berkaitan dengan competitor saat ini dan yang akan datang).

3. Bagaimana menjalankan pendidikan ke depan? (Uji asumsi dan strategi, alternatif strategi, dan pilihan strategi). Contoh: Educational Key Success: Pendidikan Sekolah Dasar Hubungan kepala sekolah yang baik

- Kompetensi teknologi yang memadai

- Memiliki chanel yang luas

- Dukungan dana yang kuat

- Reliabilitas produk (outcome)

- Inovasi yang berkelanjutan

- Regulasi yang bersaing

- Kepuasan pelanggan.

Telah disampaikan sebelumnya bahwa tidak semua 
lembaga pendidikan bisa memenuhi kriteria EKSF yang ideal karena akan menimbulkan biaya yang sangat tinggi. Tujuan sekolah adalah menyeimbangkan antara tuntutan kepuasan pelanggan (orang tua siswa) dengan keberadaan sekolah. Objeknya adalah qualified school tertentu dengan students 'achievement tertentu. Untuk itu sekolah hanya memprioritaskan Key Success Faktor yang paling esensial sesuai dengan visi dan kemampuan sekolah. Beberapa hal yang perlu diperhatikan dalam perumusan SKSF (School Key Success Factor):

1. Apakah KSF yang dipilih akan mampu mempertahankan eksistensi mutu sekolah?

2. Apakah KSF yang diplilih dapat memenuhi dinamika tuntutan pelanggan (orang tua/wali)?

3. Apakah KSF sekolah lebih baik dari pesaing (benchmarking)? Contoh: SKSF yang dimiliki dan diprioritaskan sekolah bergerak di bidang akademis. Infrastruktur (sarana-prasarana pembelajaran)

- KBM (approach, metode dan teknik pembelajaran)

- Dukungan financial yang kuat

- Product Reliability (keberhasilan Siswa)

Dengan ke 4 SKSF tersebut misalnya sekolah mendapatkan peningkatan keberhasilan (Achivement Growth) siswa sebesar 25\%. Dengan berjalannya waktu, EKSF berubah dengan lebih banyak tuntutan. Jika sekolah masih menggunakan SKSF yang lama (tidak disesuaikan), maka Achievement Growth mungkin tinggal 15\%. Hal ini disebabkan sekolah ketinggalan dalam memenuhi tuntutan pendidikan (education) atau pesaing (Competitors). Gap antara EKSF dan SKSF akan menjadi alasan bagi sekolah untuk melakukan aktifitas transformasi. Gap antara SKSF dengan competitor akan menjadi alasan bagi operasional sekolah untuk melakukan Strategic Improvement.

$\mathrm{EKSF}=$ SKSF sekolah + GAP transformasi sekolah

SKSF pesaing $=$ SKSF sekolah + GAP strategic improvement.

Contoh Aspek ketuntasan siswa antara EKSF dan SKSF dalam diagram.

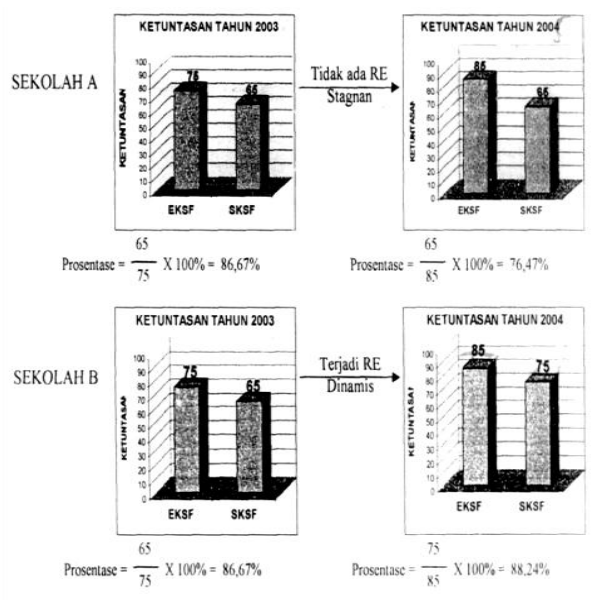

Dari diagram di atas Standar Nasional $(\mathrm{SN}) / \mathrm{EKSF}$ tahun $2004=$ 75, Sekolah A menetapkan 65, apabila tahun 2005 Standar Nasional (EKSF) menjadi 85 sedang sekolah tetap 65 maka terjadi kemunduran = 
$10,20 \%$ walaupun nilai sekolah tetap 65 seperti tahun sebelumnya. Hal ini terjadi karena pihak sekolah tidak ada usaha untuk melakukan perubahan dan pengembangan sesuai yang ditawarkan pada manajemen RE Sekolah B terjadi kenaikan $=1,57 \%$ karena mengikuti perkembangan Standar Nasional dengan menggunakan manajemen RE. Jadi dalam hal ini selalu ada peluang suatu sekolah untuk bertumbuh kembang dengan memperbaiki jarak (GAP) antara SKSF nya dengan EKSF maupun SKSF pesaing. Perlu diketahui bahwa sifat dari SKF lebih merupakan suatu syarat untuk masuk ke kwalitas pendidikan sehingga tidak mudah untuk merubah dalam periode yang relatif singkat karena memerlukan sumber daya yang banyak.

\section{SIMPULAN}

Disiplin guru merupakan
kunci keberhasilan membangun
disiplin warga sekolah dan
merupakan kunci keberhasilan
Membangun sebuah sekolah yang
ideal dan merupakan cita-cita setiap
kepala sekolah. Namun cita-cita tidak
akan terlaksana tanpa adanya
tindakan, strategi, serta
pemberdayaan sumberdaya yang ada,
termasuk bagaimana mengembangkan
manajemen sesuai dengan situasi dan
kondisi yang dimiliki oleh sebuah
sekolah. Seorang kepala sekolah
sebagai seorang manejer tentunya

memiliki peran yang banyak (multiroles) yang mampu bagaimana memotivasi, memberdayakan serta mendayagunakan semua komponen yang ada, sehingga sekolah setidaktidaknya tidak dalam kondisi status "Quo". "Kemajuan" (Improvement) adalah sebuah kata kunci dalam manajemen. Sehingga manajemen apapun termasuk RE, bila tidak ada kemajuan berarti ada 2 hal yang menjadi penyebab. Pertama, mungkin manajemennya itu sendiri yang secara sistimatis tidak tepat dan bagus. Kedua, mungkin pihak institusinya (Kepala sekolah, guru, karyawan dan stakeholder lainnya) yang belum paham serta belum mampu secara kualitas baik secara teoritis maupun implementatif. Sedangkan RE sebagai salah satu model manajemen merupakan salah satu alternatif manajemen yang mungkin dapat sebagai acuan untuk memecahkan persoalan-persoalan yang selama ini terjadi di pihak sekolah sebagai subsistem terkecil di kelembagaan pendidikan. RE yang secara implementatis dilaksanakan secara sirkuler (cycling) akan mempermudah kepala sekolah untuk mengontrol dan mengevaluasi fungsi-fungsi manajemen secara berkesinambungan dan sinergis.

Perubahan yang dinamis di dunia pendidikan, memerlukan sebuah manajemen yang dinamis pula. Tumbuhnya prinsip-prinsip manajemen justru akan menjadi 
Nurmala Tampubolon: Implementasi Manajemen ..

inspirasi dan acuan bagi sekolah Dedi Supriadi. 2003. Satuan Biaya

Nurmala Tampubolon: Implementasi Manajemen... Pendidikan Dasar dan

upayanya menuvina ualı

Menengah. Bandung:

mengembangkan sumber daya

Remaja Rosdakarya.

manusia sehingga pada gilirannya

manusia Indonesia memiliki

integritas, inisiatif, moral, intelektual,

ketrampilan dan keluwesan yang

memadai untuk menghadapi era

kesemrawutan sekarang ini. Tulisan

ini hanyalah sekapur sirih, yang manfaatnya mungkin masih terlalu kecil dibanding buku-buku manajemen pendidikan lainnya, namun betapapun kecilnya mudahmudahan bermanfaat bagi para pembaca.

Kepada para kepala sekolah yang sedang mengemban tugas mulia sebagai manajer di Sekolahnya, hendaknya selalu berinovasi untuk memperoleh salah satu bentuk manajemen yang paling efektif untuk mempercepat peningkatan mutu pendidikan di Indonesia, misalnya dengan Manajemen RE. Kepada Para birokrasdi hendaknya memberikan kesempatan yang luas kepada para kepala sekolah untuk selalu berinovasi melalui mengimplementasikan MPMBS secara total di lembaga yang dipimpinnya.

\section{DAFTAR RUJUKAN}

David P. Langford., Barbara A. Cleary. 1996. Orchestrating Learning with Quality. Synergy Books International. Bigraf Publishing.

Hernowo, Dkk. 2003. Bu Slim \& Pak Bil, Kisah tentang Kiprah Guru "Multiple Intelligences" di Sekolah. Bandung: Mizan Learning Center.

Ibtisam. 2002. .School Based Management, Logos Wacana Ilmu. Jakarta: Logos.

Indra, D. Sidi. 2001. Мепијu Masyarakat Belajar, Menggagas Paradigma Baru Pendidikan, Paramadina dengan Logos Wacana Ilmu. Telaga Kahuripan.

Jason Tan., S. Gopinathan., Ho Wah Kam. 1997. Education in Singapore, A book of Reading, National Institute of Education Nanyang Technological University. Singapore: Prentice Hall.

Murphy, Joseph and Karen Seashore Louis. 1999. Hand Book of Research on Educational Administration-A Project of The American Educational Research Association. JosseyBass Publishers.

Robert G. Owens. 1991. Organizational Behavior in Education. Allyn and Bacon United States of America.

Sudarman, Danim. 2002. Agenda Pembaruan Sistem Pendidikan. Bengkulu: 
Pustaka Pelajar Offset.

Sudjana. 2004. Manajemen Program Pendidikan-untuk Pendidikan Nonformal dan Pengembangan Sumber Daya Manusia. Falah Production.

Terry Evans and Daryl Nation. 2000.Changing University

Teaching, Reflection on Creating Educational Technologies: London Kogan Page Limited Stylus Publishing Inc.

Zamroni. 2000. Paradigma Pendidikan Masa Depan. 